\title{
ОГЛЯД ІНОЗЕМНОГО ДОСВІДУ СТАНОВЛЕННЯ ТА РОЗВИТКУ ІНСТИТУТУ ОКРЕМОЇ ДУМКИ СУДДІ КОНСТИТУЩІЙНОї ЮСТИЩІї (НА ПРИКЛАДІ ФКС ФРН)
}

\section{КУП'ЯНСЬКА Ангеліна Миколаївна - аспірантка кафедри теорії держави і права Львівського торговельно-економічного університету \\ DOI 10.32782/LAW.UA.2020.3.3}

В статье раскрьт процесс становления института особого мнения судьи Федерального Конституиионного Суда Федеративной республики Германии. Автором проведен анализ юридических норм, которье содержали положения о особом мнение. Въиделенъ особенности формирования института особого мнения в немецкой конституиионной практике. Раскрытто процедуру составления особого мнения судьей. Указано о распределении особого мнения на два вида: «concurring opinion» $u$ «dissenting opinion». Обосновъивается въивод о том, что обициальное закрепление на законодательном уровне института особого мнения судъи ФКС ФРГ мало обдуманнъий, взвешеннълй и тщательный характер.

Ключевъе слова: особое мнение, dissenting opinion, concurring opinion, конституционная юстииия, Федеральнъй конституционнъий суд, Германия.

\section{Постановка проблеми}

Інститут окремої думки судді конституційної юстиції здобув широке визнання в різних правових системах, однак ставлення до нього сучасних практиків та науковців досі характеризуються амбівалентністю. Становлення окремої думки судді конституційного суду в кожній державі має свої особливості, а тому досвід її використання та вплив на розвиток конституційної юстиції також має суттєві відмінності в залежності від країни. Особливе зацікавлення в цьому аспекті викликає практика застосування інституту окремої думки у
Федеральному Конституційному Суді Федеративної Республіки Німеччина (далі ФКС ФРН). Уже протягом багатьох років ФКС користується високим рівнем довіри у суспільстві, що підтверджується даними незалежних опитувань населення [15; 9] більше 50 \% німців регулярно оцінюють репутацію Федерального конституційного суду як добру або дуже добру. Голова ФКС Андреас Фоскуле у своєму цьогорічному дописі на сайті ФКС теж зазначає про авторитетність цього суду серед німецьких громадян [1].

Науковці дотримуються позиції, що німецький (точніше західнонімецький) Парламент був першим сучасним законодавчим органом Европи, який дозволив оприлюднити окрему думку судді [14, p.131]. ФКС ФРН має багаторічній позитивний досвід функціонування інституту окремої думки. 3 огляду на це вивчення особливостей історичного формування такого досвіду може стати прикладом для органів конституційного правосуддя України, який, станом на сьогодні, має великий запит на те, щоб отримати довіру до своєї діяльності від українського суспільства.

\section{Стан дослідження}

Проблеми становлення інституту окремої думки судді конституційного суду висвітлені у наукових працях українських науковців фрагментарно, зокрема при вивченні питань виникнення та становлення конституційного судочинства (О. Водянні- 
ков, І. Конончук, А. Портнов, В. Сабодаш, А. Селіванов, Ю. Тодика). Попри значну кількість наукових досліджень, присвячених окремій думці судді конституційної юстиції, історія формування цього інституту в країнах Европи, США та, зокрема, в Україні залишається мало дослідженою. На сьогодні в Україні досить мало фахових публікацій з проблематики історії окремої думки судді ФКС ФРН, які спиралися 6 на автентичні джерела (окремі думки різних історичних періодів функціонування ФКС, праці видатних німецьких конституціоналістів $з$ проблематики становлення інституту окремої думки). У підручниках з конституційного права зарубіжних країн історичний досвід застосування окремої думки або відсутній, або висвітлений поверхнево. Деякі аспекти становлення окремої думки судді ФРН розглянуто Н. Т. Паславською у дисертаційному дослідженні «Становлення та розвиток конституційної юстиції ФРН: історико-правове дослідження» (2015 р.).

Серед зарубіжних праць, присвячених інституту окремої думки ФКС ФРН Німеччини слід виокремити монографію угорської юристки К. Келемен «Dissent in European Constitutional Courts: A Comparative and Legal Perspective»(2018). Цікаві практично значущі дані щодо впливу окремої думки судді на конституційну юстицію Німеччини містяться в доповіді проф. I. Мюллера «Die zwei Krisen der Verfassungsrechtsprechung» (2009). Інститут окремої думки в конституційному суді Німеччини, а саме його історичні аспекти та дискусію щодо їі прийняття та практики розбіжностей при голосуванні у ФКС 3 моменту іï введення та до 1993 року були детально описані та проаналізовані німецьким юристом Йоргом Аютером у його статті під назвою «Досвід окремого голосування в німецькомовних країнах» (L'esperienza del voto dissenziente nei paesi di lingua tedesca (1994). Широкий перелік окремих думок, які більшою чи меншою мірою вплинули на думку німецької спільноти, можемо зустріти у праці адвоката Mарії Терезії Реріг (Maria Theresia Rörig). У своїй праці юристка-практик проаналі- зувала окремі думки суддів ФКС у період 3 1993 року до 2009 року від тощо.

Метою дослідження $\boldsymbol{\epsilon}$ виокремлення особливостей становлення інституту окремої думки Федерального Конституційного Суду Німеччини, що дозволить відшукати квінтесенцію ролі інституту окремої думки в розвитку конституційної юстиції ФРН.

\section{Виклад основних положень}

Найвищим органом у системі конституційного правосуддя ФРН, побудованій за європейською моделлю, є Федеральний конституційний суд Німеччини (нім. Bundesverfassungsgericht, BVerfG), який $\mathrm{E}$ незалежним від усіх інших державних органів і розташований у місті Карлсруе (земля БаденВюртемберг) [3]. Юридичну основу сучасного конституційного судочинства в Німеччині закладено Конституцією ФРН, що іменується Основним Законом (нім. Grundgesetz). Конституція ФРН була розроблена в 1948-1949 роках та набула чинності для Західної Німеччини 23 травня 1949 року. Основним Законом для всієї Німеччини Конституція 1949 року стала 3 жовтня 1990 року. На той час в Конституції ФРН було закріплено загальні положення щодо ФКС. Приписи Основного Закону закріплювали ФКС у гілці судової влади, визначали повноваження, окреслювали в загальних рисах склад суду, вибори суддів і виключали можливість поєднання цієї посади з працею у виконавчій та законодавчій владі. Конституція передбачала прийняття спеціального закону «Про Федеральний Конституційний Суд», який більш детально мав розкрити діяльність та призначення ФКС [22, с. 61$]$.

1 лютого 1951 року німецький парламент прийняв більшістю голосів перший у німецькій історії Закон «Про Федеральний Конституційний Суд». Таким чином, у 1951 році був створений ФКС ФРН, який отримав широкі повноваження [4], що, на думку вчених, стало запорукою розвитку правової держави у ФРН. Федеральний Конституційний Суд відносять до числа перших конституційних судів, які були створені в післявоєнній Европі. Як ствер- 


\section{Теорія, історія держави і права, конституційне право}

джує В. І. Сабадош, «...він (ФКС ФРН А. М. Куп'янська) виник практично на порожньому місці, оскільки ніяких процедур перегляду законів судом у Німеччині раніше не було» [23, с. 201].

Аналіз спеціального закону «Про ФКС» не залишає сумнівів щодо його змістового наповнення. Однак, незважаючи на детальний характер закону, низка важливих питань залишалася не врегульованою, в тому числі і можливість судді висловити окрему думку. Саме тому цей закон потребував численних доповнень.

Зміни, пов’язані 3 офіційним закріпленням окремої думки судді, були остаточно внесені в конституційну юстицію Нiмеччини законодавчою реформою 1970 р., через два десятиліття після створення ФКС.

Питання щодо окремої думки широко обговорювалося значно раніше 1970 року як у законодавчій, так і в юридичній науці. Перша пропозиція дозволити суддям, погляди яких залишалися в меншості, висловлювати свою незгоду 3 рішенням з'явилася вже під час підготовчої роботи Закону про судоустрій у 1880 -х роках. Однак така пропозиція була відхилена, оскільки це могло послабити єдність всередині суду, що поставило б під загрозу добрі стосунки між суддями та, як наслідок, перешкоджало 6 їх правовому розвитку, сприяло суддівському марнославству [14, p. 132]. Такі положення дають підстави стверджувати, що німці побоювалися окремих думок, які могли 6 призвести до бурхливих дискусій.

Юридичне закріплення окремої думки набуло актуальності знову після Другої світової війни. Цьому посприяло рішення Конституційного суду Бремена (одне із рішень провінції федерації) у справі, що мала вагоме суспільне та політичне значення. Згадане рішення підтвердило конституційність закону, який передбачав втрату членами Комуністичної партії місць у Державному парламенті [7]. У рішенні також були дві окремі думки, кожна 3 яких складалася трьома суддями. Вони не погодилися з більшістю у двох різних питаннях, але, враховуючи, що суд складався лише з семи членів, це означає, що лише один суддя повністю підтримав рішення. $\mathbb{E}$ достатньо підстав стверджувати, що ця справа привернула увагу до питання судового інакомислення [10, р. 540], у тому числі і науковців. У фахових колах того часу все частіше зверталися до аналізу окремої думки системи загального права $[10$, p. 541$]$.

Зважаючи на це, у 1951 р. при створенні конституційного суду, деякі члени Бундестагу підтримали ідею запровадити окрему думку, на тій підставі, що це може сприяти розвитку нової галузі права. Попри можливі переваги окремої думки суддів конституційного суду, законодавчий орган Німеччини вважав, що суспільство до цього ще не готове. Вважалося, що довіра до правосуддя ще недостатньо закріплена. Конституційному суду довелось би розбиратися у судових справах, пов'язаних iз політичними питаннями, i окремі думки могли викликати небезпечні для легітимності суду реакції громадськості $[2, \mathrm{p}$. 208]. I хоча пропозицію було відхилено, безпереч-ним $є$ те, що підхід до офіційного введення окремої думки був достатньо виваженим, обдуманим та в певній мірі обережним.

Важливу роль у подальшому утвердженні на законодавчому рівні окремої думки відіграв суддя ФКС Віллі Гейгер у справі щодо конституційного перегляду договорів Европейського оборонного співтовариства - випадок, що має важливе значення для німецької правової системи. На той час Віллі Гейгер був впливовим членом Великого сенату. Результати голосування по цій справі були оголошені громадськості у грудні 1952 року (20 суддів «за» та два «проти»). Через десять днів після прийняття рішення один $з$ двох суддів, які залишилися в меншості, Віллі Гейгер, опублікував окрему думку. Незгода судді не стосувалася головного питання справи (відповідності договорів Основному закону), а наслідків рішення. За твердженням ФКС, навіть його дорадчі висновки, такі як той, що висловлюється у згаданій справі на вимогу Федерального президента, мають обов'язкову силу та прецедентне значення у майбутніх справах, що стосують- 
ся того самого питання. Суддя Гейгер це заперечив та наполягав на тому, що ці рішення не повинні мати обов'язкової сили, оскільки сторони не були заслухані під час процедури. Обов'язковість дорадчих висновків, на думку судді, скоріше мала характер законотворчості, а не тлумачення, тому Конституційний Суд не мав повноважень заповнити цю прогалину в процесуальному законодавстві [8]. Частково внаслідок суперечки щодо обов'язковості дорадчих висновків ця компетенція конституційного суду була скасована в 1956 році [14, р. 132-133]. Як висновок, окрема думка судді Віллі Гейгера не залишилася поза увагою та однозначно вплинула на перебіг подій у майбутньому, що посприяло удосконаленню конституційної юрисдикції в Німеччині.

Попри те, що судді ФКС усе ж публікували свої окремі думки, останні так i не мали офіційного характеру та не були врегульовані законом. Наступний крок до більш прозорої процедури висловлення окремої думки був зроблений у 1966 р., коли у справі, вирішеній Першим сенатом, були опубліковані дві протилежні окремі думки, не розкриваючи при цьому, яку позицію поділяє кожен суддя [6].

У грудні 1970 року одноголосним рішенням Бундестаг змінив Закон «Про Федеральний конституційний суд». Відповідну пропозицію було винесено на розгляд соціал-демократичним урядом роком раніше. Нове правило дозволило ФКС опублікувати як окремі думки (Sondervotum німецькою мовою), так і кількість голосів за рішення Сенату. Цій реформі передували юридичні дослідження, які містять порівняльний аналіз різних правових систем, у тому числі США [16, р. 16]. Оскільки німецькі конституційні судді призначаються законодавчою владою, серед науковців з'явилося занепокоєння, що у разі їх перепризначення, це може вплинути на вільне висловленнях окремих думок [20, р. 525]. Саме тому запровадження окремих думок супроводжувалося встановленням терміну перебування на посаді судді до 12-ти років без можливості переобрання для посилення незалежності суддів [17].
Для того, щоб привести свою діяльність у відповідність до прийнятого Бундестагом рішення, ФКС вніс зміни до Регламенту 01 січня 1971 р. [17], однак перша окрема думка вже була винесена у справі кілька тижнів раніше, а саме 15 грудня 1970 року суддями Геллером, Руппом та Шлабрендорфом [5] на рішення Другого сенату. Згадана окрема думка опублікована 04 січня 1971 року [17].

Таким чином, у Законі «Про ФКС» з'явилася нова правова норма: «Суддя може висловити свою окрему думку щодо рішення або його обгрунтування; окрема думка судді долучається до рішення Суду. Сенати можуть повідомляти про співвідношення голосів у своїх рішеннях. Регламент регламентує деталі» [13, § 30 Abs. 2].

що ж все таки спонукало німецький парламент прийняти такі довгоочікувані зміни? Цікавою є думка Н. Т. Паславської, яка у своєму дисертаційному дослідженні зазначає: "Головною метою цієї інновації було досягнення більшої прозорості механізму прийняття рішень і підвищення ролі окремо взятого судді» [22, с. 27]. Як бачимо, питання окремої думки назрівало ще 3 моменту створення Федерального конституційного суду. Більше того, судді, хоч і не офіційно, але публікували свої окремі думки щодо найбільш гучних справ. Усе це, на нашу думку, було підгрунтя прийняття відповідних змін.

Норма Закону «Про ФКС», що врегульовувала питання окремої думки, мала досить загальний характер i не містила конкретних формальних вимог, процедуру прийняття та рівень юридичної сили окремої думки судді. Саме тому, більш детально про це було зазначено в Регламенті ФКС. Перший Регламент ФКС з'явився у 1975 р. Чинний Регламент ухвалено 1986 р. та опубліковано у Віснику федерального законодавства [21, с. 109].

Окрема думка судді повинна бути представлена голові Сенату протягом трьох тижнів після прийняття рішення. Сенат може продовжити цей період. Суддя, який має намір подати окрему думку, повинен повідомити про це Сенат на стадії обговорення рішення. Якщо ж 


\section{Теорія, історія держави і права, конституційне право}

окрема думка загалом підтримує рішення суду, однак має певні застереження щодо його обгрунтування, головуючий оголошує про це під час прийняття рішення. Згодом суддя може повідомити основний зміст окремої думки. Окрема думка оголошується одночасно з рішенням та має бути опублікована у збірнику рішень Федерального конституційного суду також разом 3 рішенням, із зазначенням імені судді, що висловив окрему думку [12]. Допускаються випадки, коли декілька суддів можуть висловити окрему думку спільно [22, с. 27]. Загалом, суддя повинен відображати в окремій думці свою особисту позицію.

Разом з тим, є припущення, що за своєю сутністю окрема думка певною мірою суперечить системі німецького права, якому не властива будь-яка персоналізація судів, на відміну від США, де рішення мають персоніфікований характер [18, S. 293].

у $\S 30$ Закону «Про ФКС» зазначено, що суддя може висловити свою окрему думку щодо рішення або його обгрунтування [13, § 30 Abs. 2]. Такий припис дає підстави стверджувати про розподіл окремої думки на два види:

1) dissenting opinion - коли окрема думка судді принципово відрізняється від думки більшості у резулятивній частині рішення;

2) concurring opinion - коли суддя загалом підтримує рішення більшості, однак окрема думка стосується його обгрунтування.

Окрім цього, слід також мати на увазі, що окрема думка може містити часткову згоду або незгоду щодо окремих пунктів рішення. Так, у справі про торгівлю канабісом від 9 березня 1994 року подано два види окремих думок. У першому випадку суддя Грасгоф (Graßhof) зазначає : «Я згоден 3 результатом рішення, але не 3 усіма частинами міркувань», тобто маємо справу з concurring opinion. В іншому випадку, суддя Зоммер (Sommer) розпочинає виклад окремої думки з таких слів: «Я не можу повністю погодитися $з$ рішенням Другого Сенату щодо резолютивної части- ни» [11]. Тобто в цьому випадку суддя погоджується з рішенням лише частково.

Аналіз приписів Закону «Про ФКС» та Регламенту ФКС дає підстави стверджувати, що окрема думка судді ФКС не несе юридичних наслідків, а тому має доктринальне значення. Тим не менше, безспірним є те, що попри відсутність юридичних наслідків, висловлені окремі думки все ж мають дещо інший вплив, а подекуди i значно важливіший, ніж юридичний. Мова йде про те, що офіційне закріплення права судді на окрему думку внесло певні корективи в авторитет Федерального конституційного суду Німеччини. Зрозуміло, що вплив окремої думки на діяльність ФКС мав контроверсійний характер, a його сприйняття 3 боку громадськості проявлялося як у позитивних, так і в негативних сторонах.

\section{Висновки}

Аналіз історичного досвіду становлення та розвитку інституту окремої думки судді конституційної юстиції ФРН дозволяє виділити такі факти:

1. Період становлення інституту окремої думки мав відносно тривалий характер (з 1880-х років по 1970 рік).

2. Формування інституту окремої думки судді ФКС супроводжувалося неодноразовими дискусіями та обговореннями в Бундестазі.

3. Офіційному затвердженню інституту окремої думки передувало проведення наукових досліджень, які містили порівняльних аналіз різних правових систем.

Сукупність вищезазначеного дає підстави для висунення гіпотези, що офіційне закріплення на законодавчому рівні інституту окремої думки судді ФКС ФРН не було «справою одного дня», а мало обдуманий, виважений та ретельний характер.

у рамках наступних досліджень доцільним вважається визначення історичного впливу окремої думки судді на розвиток конституційної юстиції ФКС та виокремлення позитивних і негативних моментів. 


\section{Мiтература}

1. 70 Jahre Grundgesetz und vieles mehr. URL: https://www.bundesverfassungsgericht.de/DE/Verfahren/Jahresstatistiken/2019/gb2019/vorwort.html (дата звернення 05.10.2020 р.) Назва з екрану.

2. Arthur Von Mehren. The Judicial Process : A Comparative Analysis' American Journal of Comparative Law. 1956 (5).

3. Article 1 of Federal Constitutional Court Act (Bundesverfassungsgerichts-Gesetz, BVerfGG). URL: http:// www. iuscomp. org/gla/statutes/BVerfGG.htm\# III 15 (дата звернення 05.10.2020р.)

4. Bundesverfassungsgerichtsgesetz / hrsg. von Inter Nationes. Red. : Sigrid Born. - Bonn : Inter Nationes, 1996. - $102 \mathrm{~S}$.

5. Decision of 4 January 1971, BVerfGE $30, \mathrm{I}, 33$.

6. Decision of 5 August 1966, BVerfGE 20,162 .

7. Decision of 5 January 1957 (St 2/1956) State Supreme Court of Bremen (Staatsgerichtshof der Freien Hansestadt Bremen).

8. Decision of 8 December 1952, BVerfGE $2,79$.

9. Müller I. Die zwei Krisen der Verfassungsrechtsprechung. Ein Beitrag aus der Tagung: Ein Beitrag aus der Tagung: 60 Jahre Grundrechte Entwicklungen und Gefährdungen Bad Boll, 8. - 10. Mai 2009. URL: https://www.ev-akademie-boll.de/fileadmin/ res/otg/520909-Mueller.pdf (дата звернення 09.09.2020).

10. Cohn E. J., Dissenting Opinions in German Law (1957) 6 International Comparative Law Quarterly, 540.

11. Entscheidungen des Bundesverfassungsgerichts 90, 145 vom 9. März 1994. URL: https://www.servat.unibe.ch/dfr/bv090145. html (дата звернення 20.09.2020 р.).

12. Geschäftsordnung des Bundesverfassungsgerichts. URL: https://www.gesetze-iminternet.de/bverfggo_2015/_55.html (дата звернення 14.09.2020 р.).

13. Grundgesetz für die Bundesrepublik Deutschland / Bearb. von K. Stollreither. - München : Bayerische Landeszentrale für politische Bildungsarbeit, 2000. - $266 \mathrm{~S}$.

14. Katalin Kelemen Judicial Dissent in European Constitutional Courts: A Com- parative and Legal Perspective. Routledge, 2018. 281p.

15. Köcher R. Großes Vertrauen in die deutsche Justiz. Eine Dokumentation des Beitrags von Prof. Renate Köcher in der Frankfurter Allgemeinen Zeitung. Nr. 192 vom 20. August 2014.

16. Zweigert K., Kötz H. An Introduction to Comparative Law (3rd edn, Oxford UP 1998, 744 p.) 16.

17. Meilensteine in der Geschichte des Bundesverfassungsgerichts. URL: https:// www.bundesverfassungsgericht.de/DE/ Das-Gericht/Zeitstrahl/zeitstrahl_node.htm 1 ; jessionid =9D6AF6555ECFA6 6C0E51A 2972EEC3408.1_cid370 (дата звернення 09.09.2020 p.).

18. Pestalozza Chr. Verfassungsprozessrecht : die Verfassungsgerichtsbarkeit des Bundes und der Länder mit einem Anhang zum internationalen Rechtsschutz / Christian Pestalozza. - München : Beck, 1991. - 743 S.

19. Rörig Maria Theresia. L'opinione dissenziente nella prassi del Bundesverfassungsgericht (1994-2009) (Seminario di studio, Roma, 22 June 2009) URL: https:// www.cortecostituzionale.it/documenti/ convegni_seminari/CC_SS_opinione_dissenziente_12012010.pdf (дата звернення 29.10.2020 p.).

20. Vicki C Jackson and Mark Tushnet. Comparative Constitutional Law (Foundation Press, 1999) 525.

21. Паславська Н. Т. Організація діяльності Федерального Конституційного Суду Федеративної Республіки Німеччина. $B i$ сник Аьвівського університету. Сер. : Юридична. 2014. Вип. 59. С. 108-113. URL: http:// nbuv.gov.ua/UJRN/Vlnu_yu_2014_59_17. (дата звернення 14.09.2020 р.).

22. Паславська Н.Т. Становлення та розвиток конституційної юстиції ФРН: icторико-правове дослідження. - На правах рукопису. Дисертація на здобуття наукового ступеня кандидата юридичних наук зі спеціальності 12.00.01 - теорія та історія держави і права; історія політичних і правових учень. - Львівський національний університет імені Івана Франка Міністерства освіти та науки України, Аьвів, 2015. $-210 \mathrm{c}$. 


\section{Теорія, історія держави і права, конституційне право}

у статті розкрито процес становлення інституту окремой думки судді Федерального Конституиійного Суду Федеративної республіки Німеччини. Авторкою здійснено аналіз нормативних приписів, що містили положення про окрему думку. Виокремлено особливості бормування інституту окремоі у німецькій конституиійній практиці. Розкрито процедуру оголошення окремої думки суддею. Зазначено про розподіл окремої думки на два види: “concurring opinion» ma «dissenting opinion». Обгрунтовується висновок про те, що обіиійне закріплення на законодавчому рівні інституту окремої думки судді ФКС ФРН мало обдуманий, виважений та ретельний характер.

Ключові слова: окрема думка, dissenting opinion, concurring opinion, конституційна юстиція, Федеральний конституційний суд, Німеччина.

23. Сабадош В. I. Юридична природа органів конституційного контролю в Німеччині. Держава $i$ право. № 48. 2010. C. 199-204.

\section{SUMMARY}

The article reveals the process of formation of the institution of separate opinion of a judge of the Federal Constitutional Court of the Federal Republic of Germany. The author analyzes the legal norms of a dissenting opinion. The peculiarities of the formation of a separate opinion in German constitutional practice are highlighted. The procedure for announcing a dissenting opinion by a judge is revealed. The division of a separate opinion into two types is indicated: "concurring opinion" and "dissenting opinion". The author investigated that the period of formation of the institute of dissent was relatively long (from the 1880s to 1970); the formation of the institute of dissenting opinions of the FCC judge was accompanied by repeated discussions and debates in the Bundestag; the official approval of the institute of dissent was preceded by studies that contained a comparative analysis of different legal systems.

It is reasonable to conclude that the official enshrinement at the legislative level of the institution of a dissenting opinion of a judge of the FCC of Germany was well thought out, balanced and thorough.

Key words: separate opinion, dissenting opinion, concurring opinion, constitutional justice, Federal Constitutional Court, Germany. 